This article is licensed under the Creative Commons Attribution-NonCommercial 4.0 International License (CC BY-NC) (http://www.karger.com/Services/OpenAccessLicense). Usage and distribution for commercial purposes requires written permission.

\title{
Successful Topical Treatment of Pigmented Purpuric Lichenoid Dermatitis of Gougerot-Blum in a Young Patient: A Case Report and Summary of the Most Common Pigmented Purpuric Dermatoses
}

\author{
Jeyanthini Risikesan ${ }^{a} \quad$ Mette Sommerlund $^{b} \quad$ Mette Ramsing $^{c}$ \\ Mattias Kristensen $^{b}$ Uffe Koppelhus ${ }^{b}$ \\ ${ }^{a}$ Department of Pediatrics, Aarhus University Hospital, Aarhus, Denmark; ${ }^{b}$ Department of \\ Dermatology, Aarhus University Hospital, Aarhus, Denmark; 'Department of Pathology, \\ Aarhus University Hospital, Aarhus, Denmark
}

\section{Keywords}

Gougerot-Blum · Therapy · Topical corticosteroid · Pigmented purpuric dermatoses

\begin{abstract}
We report the case of a 12-year-old girl who presented a rash with reddish-brown patches on the trunk and extremities indicative of pigmented purpuric lichenoid dermatitis of Gougerot-Blum (PPLD). The histological findings were characteristic for PPLD, thus supporting the diagnosis. Topically administered corticosteroid led to a fast resolution of all symptoms. PPLD is not seen commonly in young patients and is most often described as responding poorly to treatment with topical corticosteroids. However, the case presented here shows both that PPLD can be seen in adolescence and that the condition may be treated successful-
\end{abstract}


ly with an intense regime of topical corticosteroids. PPLD belongs to the group of pigmented purpuric dermatoses. The 5 most common pigmented purpuric dermatoses are summarized with respect to their clinical and paraclinical characteristics.

(C) 2017 The Author(s)

Published by S. Karger AG, Basel

\section{Introduction}

Pigmented purpuric lichenoid dermatitis of Gougerot-Blum (PPLD) is a chronic, relapsing, uncommon benign variant of pigmented purpuric dermatosis (PPD), first described by Gougerot and Blum in 1925. It typically affects middle-aged men, although it may present earlier in life $[1,2]$. The etiology of PPD is unknown, but triggering or contributing factors such as systemic diseases, infections, drugs, foods, venous hypertension, exercise, and capillary fragility have been suggested [3-5]. Histologically, the condition is usually characterized by extravasation of red blood cells in the dermis and/or marked hemosiderin deposition. Also, a perivascular lichenoid lymphocytic infiltrate of $\mathrm{T}$ cells centered on the superficial small blood vessels of the skin is found suggesting that cell-mediated immunity may play a role in the pathogenesis $[6,7]$. Clinically, PPLD is characterized by minute lichenoid papules that tend to fuse into plaques of various hues, with a predilection for the leg. However, unlike Schambergs disease, the lesions of PPLD may occur anywhere on the body [6]. The clinical features of PPLD may be confused with other PPDs. The PPDs are listed in Table 1a, and the differential diagnoses are presented in Table $1 \mathrm{~b}$. The pigmented purpuric lichenoid of Gougerot and Blum is likely a variant of Majocchi disease. It mainly affects middle-aged men. Majocchi disease is seen more commonly in females, unlike other PPDs. The two predominant PPDs in children and adolescents are lichen aureus and Majocchi disease. Lichen aureus and PPLD can appear as clusters of papules in children. The characteristics of the 5 most common forms of PPD with respect to the epidemiological parameters, clinical findings, histology, clinical course, and treatment possibilities are summarized in Table 2. Among the types of PPD, lichen aureus resembles PPLD the most, both clinically and histologically [1]. However, the histological pattern of PPLD is different from the pattern of the other PPDs. In the Gougerot and Blum variant of PPD, perivascular infiltrates of lymphocytes which is lichenoid are seen together with macrophages centered on the superficial small blood vessels of the skin with endothelial cell swelling and narrowing of the lumina. A skin biopsy is essential in confirming the diagnosis and to exclude cutaneous T-cell lymphoma, which in the early stages may resemble the clinical changes seen in PPD $[8,9]$.

Several regimens have been suggested for PPD including topical and systemic steroids, elastic stockings, antipruritic topical preparations, systemic antihistamines, PUVA, griseofulvin, cyclosporin A, bioflavonoids, and ascorbic acid. However, PPLD is considered difficult to treat and may often take a chronic course [2]. Here, we present a case of PPLD in a 12-yearold girl who was successfully treated with a potent topical corticosteroid. 


\section{Case Report}

A 12-year-old girl was admitted to our department 8 weeks after a sudden onset of a skin rash. The rash was initially mainly located to the trunk and later spread peripherally to both the upper and lower extremities. The face, palms, and soles were unaffected. The rash was accompanied by a mild itching. It consisted of reddish-brown patches, some of them with a lichenoid thickened appearance. The elements had diameters of 2-5 mm (Fig. 1a, b). Diascopy was negative. The girl was otherwise healthy; she had no past medical history, took no medicine prior to the skin symptoms, and had no known genetic predispositions to skin disease. Physical examination revealed no signs of infection. A broad laboratory workout was performed including infection parameters, hematology, IgE, and tryptase. Also, a punch biopsy was taken showing hyperkeratosis, acanthosis, and a predominantly superficial, papillary, diffuse, and perivascular lymphocytic infiltrate (Fig. 2a). Basal keratinocytes showed hyperpigmentation and vacuolization, and lymphocytes were found in the epidermis, often in the basal layer representing a lichenoid inflammation. Also a number of plasma cells and mast cells were present and dermal vessels were dilated and red blood cells were escaping capillaries (extravasation) (Fig. 2b). No hemosiderin was present, neither interstitially nor in macrophages.

At first, cutaneous mastocytosis was suspected and treatment with oral desloratadine, 5 mg b.i.d., was prescribed in combination with a mild regimen of topical steroid in the form of hydrocortison-17-butyrat $(0.1 \%)$ q.d. However, this treatment did not resolve any of the symptoms during the course of 2-3 weeks, and when the histological analysis was available and all the biochemical parameters were found to be normal, the diagnosis of purpuric dermatosis of the Gougerot and Blum type was made. A more intensive topical regimen with Mometasonfuroat $(0.1 \%)$ b.i.d. (thick layers) for 2 weeks followed by a slow tapering was prescribed. The treatment was accompanied an almost complete remission of the skin symptoms within 3-4 weeks. Clinical follow-up after 12 months was normal.

\section{Discussion}

PPD are well characterized in the pediatric population, but the pigmented purpuric lichenoid of Gougerot and Blum is extremely rare in children [1, 2]. In the case presented here, a 12-year-old girl presented a clinical picture consistent with a PPD and the histology was characteristic for PPLD. It should be mentioned that in purpuric lesions hemosiderin is usually present, predominantly in the dermal macrophages; however, hemosiderin takes days to accumulate - and is not necessarily seen in early lesions.

The treatment of PPD is challenging, as no specific treatment exist. As mentioned in the Introduction, several regimens have been suggested for the treatment of PPD, but the reported results are conflicting $[1,6,8,10,11]$. Treatment with a potent topical corticosteroid may be tried but is often not effective [2]. Especially PPLD seems resistant to treatment and may take a chronical course. In the case reported here, complete remission was achieved with intensive treatment with Mometasonfuroat $(0.1 \%)$. This finding may indicate that intensive treatment with a potent topical steroid should always be tried and at an as early stage of the disease as possible. 


\section{Statement of Ethics}

Informed consent for publishing the case was obtained from the patient and her parents.

\section{Disclosure Statement}

The authors report no conflicts of interest. There was no funding of this work.

\section{References}

1 Baselga E, Drolet BA, Esterly NB: Purpura in infants and children. J Am Acad Dermatol 1997;37(5 Pt 1):673-705; quiz 6-7.

2 Kim DH, Seo SH, Ahn HH, Kye YC, Choi JE: Characteristics and clinical manifestations of pigmented purpuric dermatosis. Ann Dermatol 2015;27:404-410.

-3 Sharma L, Gupta S: Clinicoepidemiological study of pigmented purpuric dermatoses. Indian Dermatol Online J 2012;3:17-20.

4 Unal E, Ergul G: Pigmented purpuric dermatosis after taking a dietary supplement. Cutan Ocul Toxicol 2016;35:260-262.

5 Weiss KT, Karrer S, Landthaler M, Babilas P, Schreml S: Diet-induced pigmented purpuric dermatosis. Australas J Dermatol 2014;55:e51-e53.

6 Sardana K, Sarkar R, Sehgal VN: Pigmented purpuric dermatoses: an overview. Int J Dermatol 2004;43:482-488.

7 Magro CM, Schaefer JT, Crowson AN, Li J, Morrison C: Pigmented purpuric dermatosis: classification by phenotypic and molecular profiles. Am J Clin Pathol 2007;128:218-229.

-8 Barnhill RL, Braverman IM: Progression of pigmented purpura-like eruptions to mycosis fungoides: report of three cases. J Am Acad Dermatol 1988;19(1 Pt 1):25-31.

-9 Toro JR, Sander CA, LeBoit PE: Persistent pigmented purpuric dermatitis and mycosis fungoides: simulant, precursor, or both? A study by light microscopy and molecular methods. Am J Dermatopathol 1997;19:108-118.

10 Kocaturk E, Kavala M, Zindanci I, Zemheri E, Sarigul S, Sudogan S: Narrowband UVB treatment of pigmented purpuric lichenoid dermatitis (Gougerot-Blum). Photodermatol Photoimmunol Photomed 2009;25:55-56.

11 Krizsa J, Hunyadi J, Dobozy A: PUVA treatment of pigmented purpuric lichenoid dermatitis (GougerotBlum). J Am Acad Dermatol 1992;27(5 Pt 1):778-780.

$\checkmark 12$ Miller K, Fischer M, Kamino H, Meehan S, Cohen D: Purpura annularis telangiectoides. Dermatol Online J 2012;18:5. 


\section{Case Reports in Dermatology}
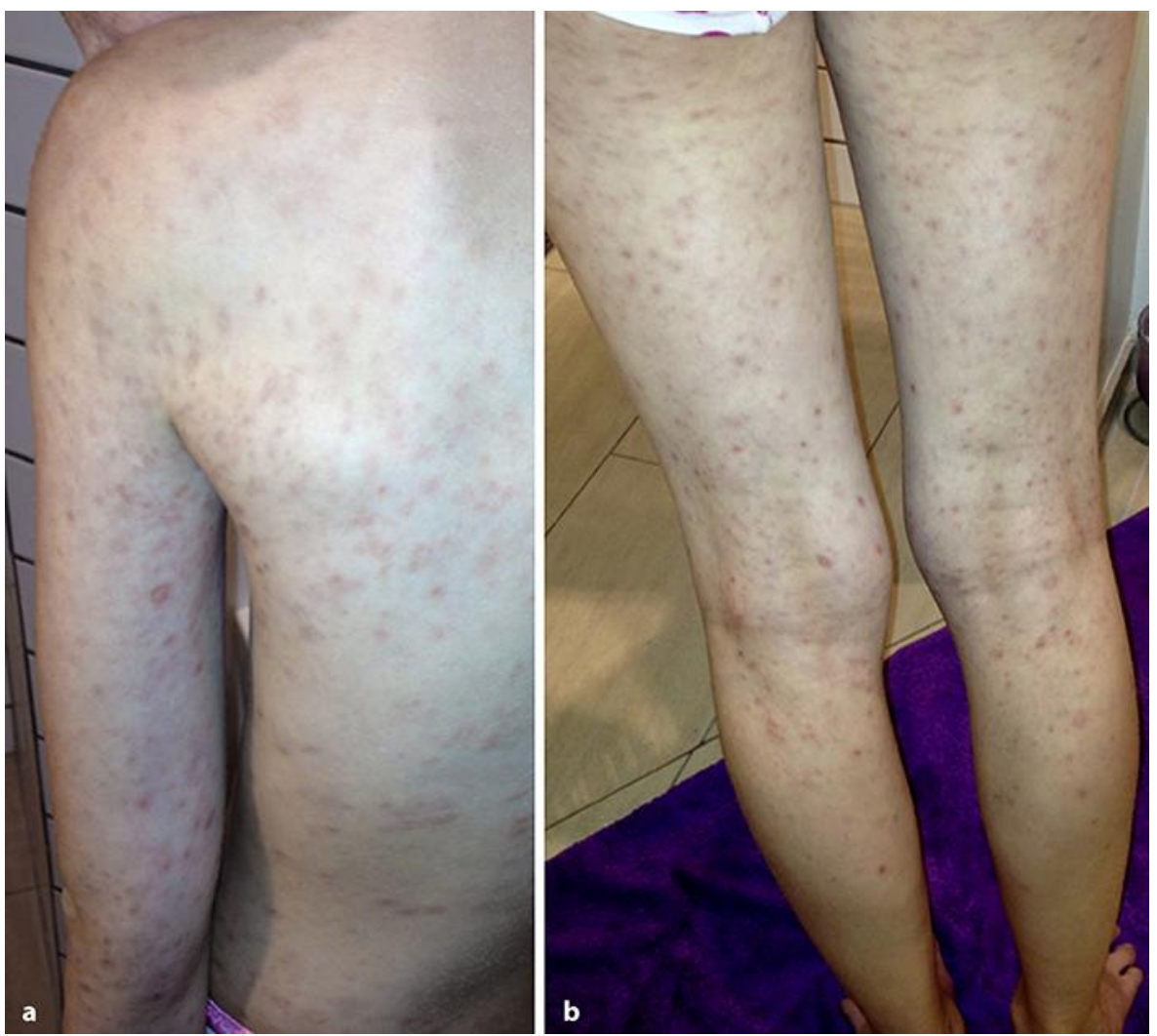

Fig. 1. Clinical features of the reported case. The rash consisted of reddish-brown patches of different thickness with diameters of 2-5 mm. The elements were located to the trunk (a) and (especially the proximal parts of) the over and under extremities (b). Only a few excoriations were seen. (Private photos courtesy of the patient's farther.) 


\section{Case Reports in Dermatology}

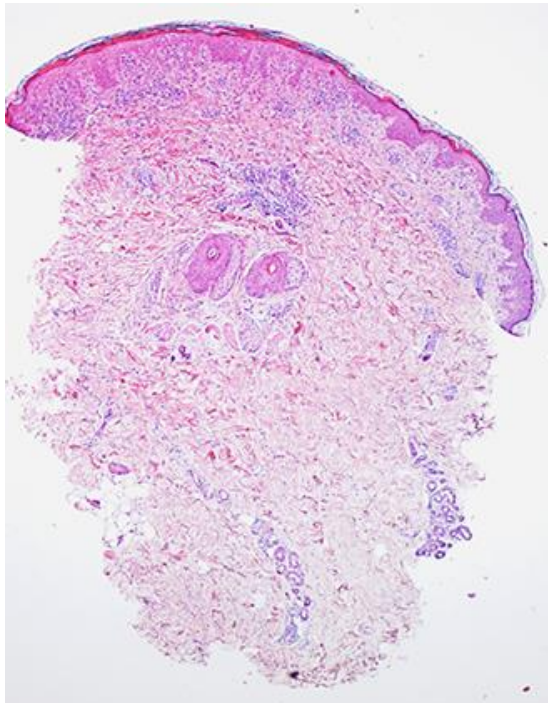
a

Fig. 2. Histological features of the reported case. Punch biopsy from the hip showed hyperkeratosis, slight acanthosis, and a superficial lymphocytic infiltrate, most prominent in the papillary dermis. There is perivascular accentuation of the inflammation (HE $\times 40)(a)$.The basal keratinocytes show hyperpigmentation and vacuolization, and lymphocytes are found in the epidermis (lichenoid dermatosis). A diffuse and perivascular lymphocytic infiltrate is seen, capillaries are dilated, and there is extravasation of red blood cells (purpura) $(\mathrm{HE} \times 400)(\mathbf{b})$. 
Table 1. Classification of the PPDs (a) and their differential diagnoses (b)

\section{a Classification of the PPDs}

1. Majocchi disease (1896) - purpura annularis telangiectaticum

2. Schamberg disease (1901)

3. Pigmented purpuric lichenoid dermatosis of Gougerot and Blum (1925)

4. Eczematoid-like purpura of Doucas and Kapetanakis (1953)

5. Itching purpura of Lowenthal (1954)

6. Lichen purpuricus (Martin, 1958; Haber, 1958), lichen aureus (Calnan, 1960)

7. Transitory PPD (Osment, 1960)

8. Linear PPD (Hersh and Schwayder, 1991)

9. Granulomatous variant (Saito and Matsuoka, 1996)

\section{b Differential diagnoses}

1. Purpuric drug eruption:

- Carbromal-containing medications

- acetyl, carbromal, meprobamate, mephenesin

- Phenacetin

- Barbiturates

- Chlorothiazide

- Gold

- Isoniazid

- Quinidine

- Sulfonamides

- Ampicillin

- Zomepirac sodium

2. Clothing purpura after contact with

- Wool

- Rubberized underwear

- Elasticized underwear

3. Stasis purpura (venous)

4. Thrombocytopenia

5. Hypergammaglobulinemic purpura

6. Senile purpura

7. Henoch-Schönlein purpura

8. Viral illness

9. Kaposi sarcoma

10. Mycosis fungoides can present with an early eruption resembling PPD

Adapted from [6] (a) and [2] (b). PPD, pigmented purpuric dermatosis. 
Risikesan et al.: Successful Topical Treatment of Pigmented Purpuric Lichenoid

Dermatitis of Gougerot-Blum in a Young Patient

Table 2. The clinical and paraclinical characteristics of PPLD and the 4 most common differential diagnoses

\begin{tabular}{|c|c|c|c|c|c|}
\hline & $\begin{array}{l}\text { Majocchi } \\
\text { disease }\end{array}$ & $\begin{array}{l}\text { Schamberg } \\
\text { disease }\end{array}$ & PPLD & $\begin{array}{l}\text { Eczematoid-like purpu- } \\
\text { ra of Doucas and } \\
\text { Kapetanakis }\end{array}$ & Lichen purpuricus (aureus) \\
\hline Sex & $\begin{array}{l}\text { Predominantly seen in } \\
\text { females }\end{array}$ & $\begin{array}{l}\text { Predominantly seen in } \\
\text { males }\end{array}$ & $\begin{array}{l}\text { Predominantly seen in } \\
\text { males }\end{array}$ & $\begin{array}{l}\text { Predominantly seen in } \\
\text { males }\end{array}$ & Both sexes \\
\hline Frequency & Rare & $\begin{array}{l}\text { Most common type of } \\
\text { PPD }\end{array}$ & Rare & Uncommon & Rare \\
\hline $\begin{array}{l}\text { Peak } \\
\text { incidence }\end{array}$ & Children and young adults & $\begin{array}{l}\text { Adolescents and } \\
\text { young adults }\end{array}$ & Middle-aged & Middle-aged & Children and young adults \\
\hline $\begin{array}{l}\text { Skin } \\
\text { distribution }\end{array}$ & $\begin{array}{l}\text { Begins on the lower limb } \\
\text { symmetrically and then } \\
\text { extends to the trunk and } \\
\text { upper extremities }\end{array}$ & $\begin{array}{l}\text { Most frequently } \\
\text { bilaterally on the tibial } \\
\text { regions, but may be } \\
\text { unilateral or involve } \\
\text { the thighs, buttocks, } \\
\text { trunk, or upper } \\
\text { extremities }\end{array}$ & $\begin{array}{l}\text { Predilection for the legs, } \\
\text { and rarely on the trunk } \\
\text { and thighs }\end{array}$ & $\begin{array}{l}\text { Legs with progression to } \\
\text { the thighs, trunk, and } \\
\text { upper extremities }\end{array}$ & $\begin{array}{l}\text { Lesions frequently occur } \\
\text { bilaterally on the lower } \\
\text { limbs, although can be } \\
\text { unilateral and may affect } \\
\text { the trunk and upper limbs; } \\
\text { unlike other forms of PPD, } \\
\text { the lesions of lichen aureus } \\
\text { may also occur in a derma- } \\
\text { tomal distribution, or can } \\
\text { follow the distribution of } \\
\text { veins or arteries }\end{array}$ \\
\hline $\begin{array}{l}\text { Clinical } \\
\text { presentation }\end{array}$ & $\begin{array}{l}\text { Variable number of annular } \\
\text { erythematous plaques and } \\
\text { patches, often with central } \\
\text { clearing and atrophy }\end{array}$ & $\begin{array}{l}\text { Discrete reddish- } \\
\text { brown patches that } \\
\text { are bordered from red } \\
\text { to brown; nonpalpa- } \\
\text { ble, pinpoint puncta; } \\
\text { Cayenne pepper- like } \\
\text { lesions }\end{array}$ & $\begin{array}{l}\text { Minute, lichenoid papules } \\
\text { that tend to fuse into } \\
\text { plaques of various hues }\end{array}$ & $\begin{array}{l}\text { Lesions are extensive } \\
\text { and patients typically } \\
\text { complain of severe } \\
\text { pruritus }\end{array}$ & $\begin{array}{l}\text { Presents with yellowish or } \\
\text { red papules or patches } \\
\text { which may either itch or be } \\
\text { asymptomatic }\end{array}$ \\
\hline Histology & $\begin{array}{l}\text { Perivascular and predomi- } \\
\text { nantly band-like infiltrate of } \\
\text { lymphocytes that extend to } \\
\text { the overlying epidermis, } \\
\text { showing vacuolar alteration } \\
\text { of the basal layer and } \\
\text { spongiosis; hemosiderin- } \\
\text { laden macrophages, and } \\
\text { extravasation of red blood } \\
\text { cells within the lichenoid } \\
\text { infiltrate }\end{array}$ & $\begin{array}{l}\text { Perivascular infiltrate } \\
\text { of mononuclear cells } \\
\text { in the upper dermis, } \\
\text { endothelial cell } \\
\text { swelling, extravasated } \\
\text { red blood cells, and } \\
\text { hemosiderin-laden } \\
\text { macrophages }\end{array}$ & $\begin{array}{l}\text { Perivascular infiltrate of } \\
\text { lymphocytes which is } \\
\text { lichenoid and macrophag- } \\
\text { es centered on the superfi- } \\
\text { cial small blood vessels of } \\
\text { the skin with endothelial } \\
\text { cell swelling and narrow- } \\
\text { ing of lumina }\end{array}$ & $\begin{array}{l}\text { Spongiosis with inflam- } \\
\text { mation of the epidermis }\end{array}$ & $\begin{array}{l}\text { Perivascular lymphohistio- } \\
\text { cytic infiltrate in a band- } \\
\text { like pattern; hemosiderin- } \\
\text { laden macrophages, and } \\
\text { extravasation of red blood } \\
\text { cells; the epidermis is } \\
\text { unaffected }\end{array}$ \\
\hline Remission & Common & Common & $\begin{array}{l}\text { Often chronic course but } \\
\text { spontaneous remission } \\
\text { may occur }\end{array}$ & $\begin{array}{l}\text { Spontaneous remission } \\
\text { may occur, but recur- } \\
\text { rences may occur }\end{array}$ & $\begin{array}{l}\text { Spontaneous remission } \\
\text { may occur, but recurrences } \\
\text { may occur }\end{array}$ \\
\hline Treatment & $\begin{array}{l}\text { The disorder is benign and } \\
\text { self-limiting; treatment is } \\
\text { not effective and the lesions } \\
\text { may last several months to } \\
\text { years }\end{array}$ & $\begin{array}{l}\text { Systemic steroids have } \\
\text { been reported to } \\
\text { result in clearance; } \\
\text { ascorbic acid and } \\
\text { antihistamines have } \\
\text { been used with limited } \\
\text { success; PUVA therapy } \\
\text { is beneficial; narrow } \\
\text { band UVB }\end{array}$ & $\begin{array}{l}\text { Difficult; topical and } \\
\text { systemic steroids, elastic } \\
\text { stockings, antipruritic } \\
\text { topical preparations, } \\
\text { systemic antihistamines, } \\
\text { PUVA, griseofulvin, cyclo- } \\
\text { sporin A, bioflavonoids, } \\
\text { and ascorbic acid have } \\
\text { been suggested }\end{array}$ & $\begin{array}{l}\text { Topical corticosteroids } \\
\text { and antihistamines }\end{array}$ & $\begin{array}{l}\text { Oral corticosteroids; may } \\
\text { resolve spontaneously }\end{array}$ \\
\hline
\end{tabular}

Extracted from [2, 6, 9-12]. PPLD, pigmented purpuric lichenoid dermatitis of Gougerot-Blum; PPD, pigmented purpuric dermatosis. 